\title{
ANALYSIS OF OPERATION PERFORMANCE IN THE PROCESS OF MACHINE WOOD HARVESTING WITH FAO FAR 6840 MINI-HARVESTER
}

\author{
Mariusz Kormanek ${ }^{*}$, Dariusz Baj \\ Department of Forest Work Mechanisation, University of Agriculture in Krakow
}

"Corresponding author: rlkorma@cyf-kr.edu.pl

\begin{tabular}{l}
\hline ARTICLE INFO \\
\hline Article history: \\
Received: November 2017 \\
Received in the revised form: \\
December 2017 \\
Accepted: Junuary 2018 \\
\hline Key words: \\
harvester, \\
timber harvesting, \\
harvester performance \\
\\
\end{tabular}

\begin{abstract}
\end{abstract}
\section{Introduction}

A harvester is a popular multi-operational machine used in the Polish forests (Glazar and Maciejewska, 2008). These are machines, which as a rule perform cutting, pruning and logging (Skarżyńskie and Brzózko, 2010). Savings in labour force (one person operation), increase in forest farming, precise recording of the performed work, fast removal of wood raw material in case of natural disasters, work safety and hygiene, fast reaction to the recipients' needs, maintaining cleanness of the logged wood and limitation of damages in forest stands and on the surface of soil are advantages of using harvesters (Dvorak et al., 2015). The first harvesters in Poland have appeared under the end of the 80 s when fully mechanized logging was initiated by the State-owned Forest Farm by purchase of Makersi 34T harvesters for thinning (Błuszkowska and Nurek, 2016). In Poland in 2001 there were 10 harvesters working and the highest increase of their number took place in $2006-2008$ when the number of harvesters increased to more than 120 pieces. In 2010 there were as much as 160 types of this machine and in 2011- 351 (Informacja RDLP, 2010; Skarżyński and Brzózko, 2010). In 2014460 harvesters were reported in Poland and at the end of 2016 
approximately 530. It means that these machines are permanently used in forestry (Mederski et al., 2016). Due to the fact that in our country more than $75 \%$ of the forest area is occupied by coniferous forest stands as well as due to the growth of logged wood the use of these machines on a large scale may be applied (Mederski et al., 2016; Skarżyski and Brzózko, 2010). In Poland in 2009 harvesting with multi-operational machines constituted approximately 5\% of the wood mass obtained in State-owned Forests and in 2012 as much as $10 \%$ of wood was harevsted in Poland (Sowa et al., 2013). Fast grow of the number of multi-operational machines is slowed down by a high purchase and exploitation costs of machines, low manual work costs, species structure of forest stands, small-area chipping, no concentration of works, high requirements regarding labour organization, timeconsuming and cost-consuming repairs as well as a long-term and expensive process of training of operators (Błuszkowska and Nurek, 2016; Dvorak et al., 2015, Sowa et al., 2013). With regard to these obstacles there is still a need of searching for new solutions which would be more adjusted to the requirements of the sustainable forest farming which combines requirements of ecology, ergonomics and work safety and relevant efficiency of performed tasks (Moskalik, 2004). One of the methods for greater availability of harvesters is the use of small, cheap machines, constructed based on the existing structural solutions. One of the examples of this type of a machine is Fao Far 6840 mini harvester constructed based on ATLAS loader. The objective of the paper was analysis of performance of this type of a machine at the machine wood harevsting based on the working day timing.

\section{Materials and methods}

The research was carried out on the territory of Lubliniec Forest Inspectorate, Bór Forestry. The investigated area was in the timberland where the age of the forest stand was 65 years old, the index of stand density 0.9 , medium interrupted density, medium density, habitat forest type mixed fresh forest, moisture variant - strongly fresh, natural habitat, flat forest land. A forest stand consists mainly of pine and the tree stand is compliant with the habitat. On the research area, late negative thinning due to disasters forced by damage from thuft was carried out. Works were performed with the use of Fao Far 6840 harvester equipped with Arbo Stroke $400 \mathrm{~S}$ head (fig 1, tab. 1). Fao Far 6840 is a machine made on the base of German loader ATLAS. The main reconstruction of the loader was performed at the machine producer in Germany where the measurement system Arbro Mat S, safety framework on the windscreen, crane and hydraulic system distributor were mounted. ARBRO 400 S Finnish head was mounted in FAO FAR and its characteristic feature is that it uses a telescope driven by the hydraulic actuator for moving wood during pruning. Operational parameters of the machine on the site were determined based on the working day timing. It consisted in measuring with a stopwatch (precision $\pm 0.5 \mathrm{~s}$ ) of the time necessary to reach and return from the area where harvesting and video recording was performed with Sony CCD TR600 camera of the harvester's operation from the moment it reached the site. The total time of recording was almost 6 hours and included 93 full treatment cycles. 
Analysis of operation...

Table 1.

Basic technical data of Fao Far 6840 and Arbo Stroke 400 S head

\begin{tabular}{|c|c|c|c|c|c|}
\hline \multicolumn{6}{|c|}{ Mini harvester Fao Far 6840} \\
\hline Specification & Unit & Valu & eSpecification & Unit & Value \\
\hline Height/width & (m) & $\begin{array}{l}2.62 / \\
2.19\end{array}$ & $\begin{array}{l}\text { Engine Deutz TD } 2011 \\
10114 \mathrm{i}\end{array}$ & $\begin{array}{l}\text { number of } \\
\text { cylinders }\end{array}$ & 4 \\
\hline Distance between axes & (m) & 1.97 & Engine capacity & $\left(\mathrm{m}^{-3}\right)$ & 3.243 \\
\hline $\begin{array}{l}\text { Transport distance/ arm } \\
\text { stretched }\end{array}$ & (m) & $\begin{array}{l}5.25 / \\
555\end{array}$ & Power/maximum torque & $\begin{array}{l}(\mathrm{kW}) / \\
(\mathrm{Nm})\end{array}$ & $\begin{array}{c}59.5 / \\
245\end{array}$ \\
\hline turning radius & (m) & 3.5 & Maximum driving speed & $\left(m \cdot s^{-1}\right)$ & 5.55 \\
\hline $\begin{array}{l}\text { Operational scope from the } \\
\text { turning radius of the arm }\end{array}$ & (m) & 6.9 & $\begin{array}{l}\text { Output / hydraulic pumps } \\
\text { pressure } \\
\text { (lift and head) }\end{array}$ & $\begin{array}{c}\left(\mathrm{m}^{3} \cdot \mathrm{h}^{-1}\right) / \\
(\mathrm{MPa})\end{array}$ & $\begin{array}{c}19.2 \\
34\end{array}$ \\
\hline Gross lifting moment & $\mathrm{kNm}$ & 43 & $\begin{array}{l}\text { Output / hydraulic pumps } \\
\text { pressure (driving system) }\end{array}$ & $\begin{array}{c}\left(\mathrm{m}^{3} \cdot \mathrm{h}^{-1}\right) / \\
(\mathrm{MPa})\end{array}$ & $\begin{array}{c}2 \times 18 \\
40\end{array}$ \\
\hline Operational mass & $(\mathrm{kg})$ & 6240 & Tyres width & (m) & 0.625 \\
\hline \multicolumn{6}{|c|}{ Arbro Stroke $400 \mathrm{~S}$ Head } \\
\hline Maximum oil flow & $\left(m^{3} \cdot h^{-1}\right)$ & 5.4 & Mass (without oil) & $(\mathrm{kg})$ & 300 \\
\hline Maximum working pressure & $(\mathrm{MPa})$ & 20 & Maximum pruning diameter & (m) & 40 \\
\hline Rotator rotational angle & $\left({ }^{\circ}\right)$ & $\infty$ & Felling diameter & (m) & 0.4 \\
\hline Feed speed & $\left(\mathrm{m} \cdot \mathrm{s}^{-1}\right)$ & 0.35 & Measuring control system & - & Arbro Mat S \\
\hline
\end{tabular}

Determination of the log volume was made based on the measurement of the diameter of 35 trees (with the use of a circumeter with precision up to $+1 \mathrm{~cm}$ ) of the first cutlog of each tree in the thicker end and the last one in the thinner end. Length of the remaining trees was determined based on the logs made and recorded by the machine. During the works, logs with the length of $2.5 \mathrm{~m}$ were made. Their length was programmed in the machine control system Arbro Mat S. Additionally five randomly selected and made stacks were taken down with the use of the measuring tape with precision up to $\pm 1 \mathrm{~cm}$, in order to control the measurement of logs by the computer. Based on two diameters and length of a tree, $\log$ volume of particular trees which were marked with subsequent numbers were calculated. It enabled measurement of the duration of particular technological operations with regard to particular trees. Log volume of particular trees $V_{s}\left(\mathrm{~m}^{3}\right)$ was calculated with Smalian's formula (Jaszczak and Magnuski, 2010), and the total $\log$ volume $\mathrm{V}\left(\mathrm{m}^{3}\right)$ as a sum of $\log$ volume of trees harvested within one working day. Particular components of work time were separated based on the measurement with a stopwatch and from the recording according to the agricultural standard, adjusted to the forestry requirements in Poland (BN-76/9195-01; Szewczyk and Kulak 2015). 

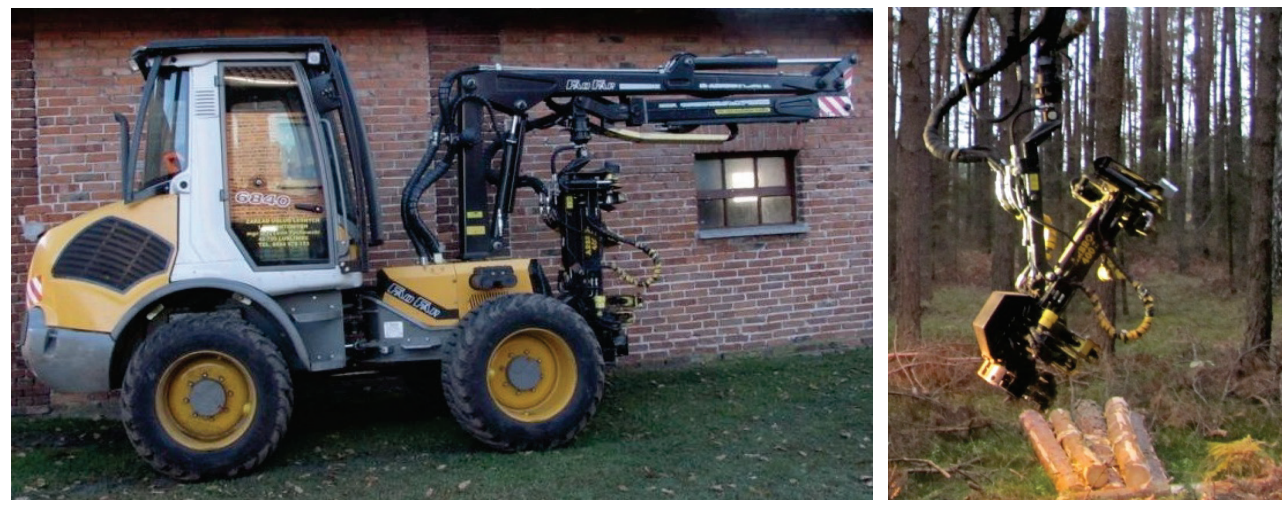

Figure 1. Fao Far 6840 mini harvester, Arbo Stroke 400 S head during operation -b

Components of the timing such as: effective operation time $T_{1}$ which comprised the time of felling $T_{11}$ and time of delimbing and bucking $T_{12}$; auxiliary time $T_{2}$ which comprised technological crossings between trees $T_{21}$, as well as time of technological stopovers related to marking trees for cutting $T_{22}$; time of daily technical service $T_{3}$; time of removing faults $T_{4}$ which comprised the removal time of technological $T_{41}$ and technical faults $T_{42}$; relax time $T_{5}$; transport crossings time $T_{6}$; technical service time of a harvester not related to starting and technical service of working units of the machine $T_{7}$. Based on the measured times the operational working time of the machine $T_{02}$, working time of the shift $\mathrm{T}_{04}$ and operational time of the shift $T_{07}$ were calculated. Based on the operation time balance the following were calculated: coefficient of using the operational time $K_{02}$; coefficient of using the working time of shift $K_{04}$; coefficient of using the operational time of shift $K_{07}$; auxiliary coefficient which characterizes technical certitude $K_{42}$ (BN-77/9195-02). Using the operation time balance of the machine the following were calculated:

- operational performance of the harvester operation time (1):

$$
W_{1}=V \cdot\left(T_{1}+\mathrm{T}_{21}\right)^{-1}\left(\mathrm{~m}^{3} \cdot \mathrm{h}^{-1}\right)
$$

- performance in the operational work time (2)

$$
W_{02}=V \cdot T_{02}{ }^{-1}\left(\mathrm{~m}^{3} \cdot \mathrm{h}^{-1}\right)
$$

- performance in the operational work time (3):

$$
W_{04}=V \cdot T_{04}^{-1}\left(\mathrm{~m}^{3} \cdot \mathrm{h}^{-1}\right)
$$

- performance in the operational work time (4):

$$
W_{07}=V \cdot T_{07}{ }^{-1}\left(\mathrm{~m}^{3} \cdot \mathrm{h}^{-1}\right)
$$


Analysis of operation...

\section{Analysis of results and discussion}

As a result of the measurements and analyses it was stated that during the cycle of treatment of one tree, felling $T_{11}$ lasted at the average $-18.2 \%(22.5 \mathrm{~s})$. As a rule only one cutting was performed which resulted in tree felling. There were two situations when felling was long ( $1 \mathrm{~min} 26 \mathrm{~s}$, and $1 \mathrm{~min} 51 \mathrm{~s}$ ) which was related to suspension of the felt tree. Relation (figure 2a) of the duration of felling to the breast height diameter of trees (for a sample of 35 trees) has a low value of the determination coefficient which proved high variability of the duration of this treatment for trees with a similar diameter. Similar results were obtained by Sadowski et al., (2014) or Kormanek and Kępa (2016). Except for suspension of trees, the variability resulted from situations when the operator felt trees too fast and a piece of wood was torn off and the tree had to be cut again which considerably prolonged the duration of felling. These situations resulted from both difficulties of harvesting on a particular area but also short experience of the machine operator.

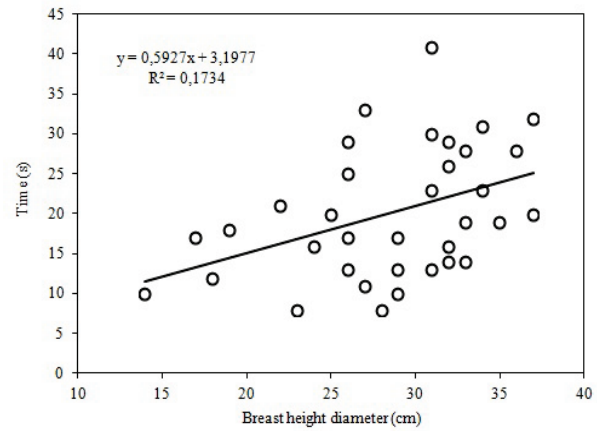

$\mathrm{a}$

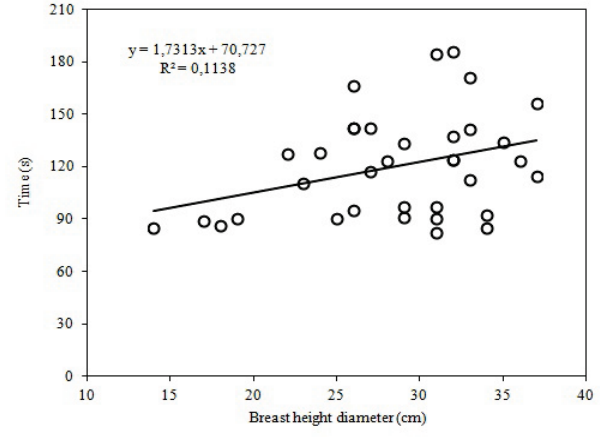

$\mathrm{b}$

Figure 2 Relation of the breast height diameter and the felling time and the delimbing and bucking time $-b$

Delimbing and bucking time $T_{12}$ which was as much as $81.8 \%$ (at the average $100.7 \mathrm{~s}$ ) constituted the remaining processing time of a single tree (table 2, fig. 2b). The high percentage share of this time was affected by the bucking time related to the duration of the log production and the time of delimbing. A $2.5 \mathrm{~m}$ log was made which was in demand at that time which at usual production of 5 cutlogs of one tree forced to make 4 cuttings. The process of delimbing with the head of Arbo $400 \mathrm{~S}$ was long (fig. 2b) because of the head structure and to- and fro- motion which drives the hydraulic cylinder. The feed speed in this case during bucking is only $0.35 \mathrm{~m} \cdot \mathrm{s}^{-1}$ while for heads with a wheel and roll drive of the feed it fluctuates within the range of approximately $3 \mathrm{~m} \cdot \mathrm{s}^{-1}$ for small heads (Log Max 928A with the weight of $407 \mathrm{~kg}$ ) to $7 \mathrm{~m} \cdot \mathrm{s}^{-1}$ big heads (SP $591 \mathrm{LX}$ with the weight of $1700 \mathrm{~kg}$ ) (Sowa et al., 2013). Relation (fig. 2b) of the duration of bucking and delimbing to the breast height diameter of trees (for a sample of 35 trees) has a low determination coefficient value which proved high variability of the duration of these treatments for trees with similar diameters, similar results were obtained by Sadowski et al., (2014). Effective operation time $T_{l}$ (fig. 3, 
table 2) for 6 hour working shift was 3 h 10 min $58 \mathrm{~s}$, which constitutes $53.0 \%$ of time in the operational shift time.

Table 2 .

Working day components

\begin{tabular}{lcccccccc}
\hline Parameter & Unit & Result & Parameter & Unit & Result & Parameter & Unit & Result \\
\hline $\mathrm{T}_{1}$ & $(\mathrm{~s})$ & 11458 & $\mathrm{~T}_{23}$ & $(\mathrm{~s})$ & 1078 & $\mathrm{~T}_{6}$ & $(\mathrm{~s})$ & 1350 \\
$\mathrm{~T}_{11}$ & $(\mathrm{~s})$ & 2090 & $\mathrm{~T}_{31}$ & $(\mathrm{~s})$ & 600 & $\mathrm{~T}_{7}$ & $(\mathrm{~s})$ & 0 \\
$\mathrm{~T}_{12}$ & $(\mathrm{~s})$ & 9368 & $\mathrm{~T}_{4}$ & $(\mathrm{~s})$ & 300 & $\mathrm{~V}_{\mathrm{s}}$ & $\left(\mathrm{m}^{3}\right)$ & 0.62 \\
$\mathrm{~T}_{21}$ & $(\mathrm{~s})$ & 5664 & $\mathrm{~T}_{5}$ & $(\mathrm{~s})$ & 1170 & $\mathrm{~V}$ & $\left(\mathrm{~m}^{3}\right)$ & 57.66 \\
\hline
\end{tabular}

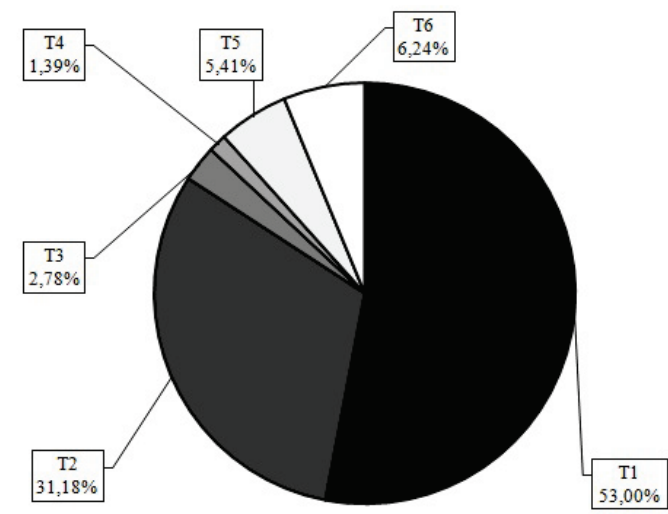

Figure 3. Shift operational time structure

Technological crossings time $T_{21}$ of getting to another tree was considerable, at the average ca. 1 minute $(26.2 \%)$ and resulted from great distance between trees which was from 10 to $15 \mathrm{~m}$ and which was related to average density (stand density 0.9 ) and growth phase of the forest stand (thin forest stand). The average time of the harvester operation cycle which is the total time of processing operations of wood $T_{1}$ with time indispensable for accessing a tree $T_{21}$ in the investigated case was $184 \mathrm{~s}$ ( 3 minutes and 4 seconds). This time is comparable to the duration of the treatment cycle of a single tree with Highlander harvester (Kormanek and Kępa, 2016) which was 195.5 s (3 min 15.5 s). However, in case of Highlander the average volume of the processed wood was almost twofold higher and it was $1.017 \mathrm{~m}^{3}$ while for the mini harvester it was only $0.63 \mathrm{~m}^{3}$. As a rule, an important factor which may affect the length of the technological crossing durations $T_{21}$ in the timing is the operator's organization of work. In this case, based on observations one may state that the operator's work organization was good, crossing took place as a rule with the shortest possible route. Technological stopovers time $T_{23}$ related to marking the trees for felling (the operator marked the trees by himself) was considerably short and it was $17 \mathrm{~min} 58 \mathrm{~s}$, which 
Analysis of operation...

constitutes $4.9 \%$ of the working shift time. The time of daily technical service $T_{31}$ was 10 minutes $(2.78 \%)$ and also was satisfactory. The time was related to starting of the machine, warming up the engine and achieving relevant level of pressure and oil temperature in the system of hydraulics of the mini harvester. In time when the machine was started, the operator checked the general condition of the machine (condition of oil in the engine and hydraulic system, air pressure in tyres, general condition of the head and chain in the cutting system, he also performed indispensable smearing of sub-assemblies). During the analysed working day, the time of removal of technological faults $T_{4 l}$ did not occur and the removal time of technical faults $T_{42}$ was the least time consuming activity and it took only 5 minutes $(1.39 \%)$ in the general working shift time. The repair concerned the hydraulic hose of the harvester head which was catching its arm during extension which as a result disturbed complete extension of the telescope end and as a result caused erroneous measuring out of $\operatorname{logs}$ to the programmed length. Elimination of the fault consisted in the improvement of hose mounting. Break and physiological needs time $T_{5}$ in this case was also short. Only its slight participation in the total operational time with the value of $5.41 \%$ was reported which corresponds to 19 minutes and 30 seconds. Transportation crossing time T6, namely the time of reaching and return to the place of stationing was 22 minutes and 30 seconds which constitutes $6.3 \%$ in the operational time of the shift and it is a good result. The area where the mini harvester was used was only $700 \mathrm{~m}$ from the place when the machine was parked. Storing the mini harvester at the private property of the farmer who lives by the forest was a good solution. A failure to apply this solution would extend by several times the time necessary to go from the base to the work place. Another possible solution which would practically eliminate the time related to reaching the work place would be leaving the machine directly in the forest. This solution is quite risky due to the possibility of theft or devastation of equipment thus it is not used in practice. During the research on the working day, $T_{7}$ time of technical service of the harvester not related to starting and technical service of working units of the machine was not specified. The machine was quite new and not much used. Operation time use ratio (table 3 ) $K_{02}$ was only 0.63 which was considerably influenced by the time lost on reaching the tree $T_{21}$. A similarly low value was assumed by the working time use coefficient $K_{04}$ equal to 0.60 with a small participation of the time of daily technical service $T_{3}$ and the removal time of technical faults T42. Coefficient of the exploitation use of the shift time $K_{07}$, was 0.53 and this value may be considered low. The value of this coefficient indicates that almost half of the 6-hour working day is not used for effective performance of work. While, the coefficient of technical certitude $K_{42}$ was high as much as 0.98 and related to the lack of serious faults of the mini harvester which resulted mainly from the fact that the machine was quite new and not much used.

Table 3.

Machine working day balance

\begin{tabular}{ccccccccc}
\hline Parameter & Unit & Result & Parameter & Unit & Result & Parameter & Unit & Result \\
$\mathrm{T}_{02}$ & $(\mathrm{~s})$ & 18180 & $\mathrm{~K}_{04}$ & - & 0.60 & $\mathrm{~W}_{02}$ & $\left(\mathrm{~m}^{3} \cdot \mathrm{h}^{-1}\right)$ & 11.42 \\
$\mathrm{~T}_{04}$ & $(\mathrm{~s})$ & 19080 & $\mathrm{~K}_{07}$ & - & 0.53 & $\mathrm{~W}_{04}$ & $\left(\mathrm{~m}^{3} \cdot \mathrm{h}^{-1}\right)$ & 10.88 \\
$\mathrm{~T}_{07}$ & $(\mathrm{~s})$ & 21600 & $\mathrm{~K}_{42}$ & - & 0.98 & $\mathrm{~W}_{07}$ & $\left(\mathrm{~m}^{3} \cdot \mathrm{h}^{-1}\right)$ & 9.61 \\
$\mathrm{~K}_{02}$ & - & 0.63 & $\mathrm{~W}_{1}$ & $\left(\mathrm{~m}^{3} \cdot \mathrm{h}^{-1}\right)$ & 12.14 & & & \\
\hline
\end{tabular}


The operational performance of the harvester operation cycle (1) calculated as the sum of times of single tree processing and reaching it $W_{l}$ amounting to $12.14 \mathrm{~m}^{3} \cdot \mathrm{h}^{-1}$ (average volume was $0.62 \mathrm{~m}^{3}$ ) was slightly lower than the performance of the thinning harvester Valmet 901.3 (machine power $140 \mathrm{~kW}$ ) operating on the late thinning area where the stand density was 0.8 and the volume of the average piece was $0.56 \mathrm{~m}^{3}$ (Maksymiak and Grieger, 2008). Operational performance of Valmet in this case was at the level of $12.32 \mathrm{~m}^{3} \cdot \mathrm{h}^{-1}$. On the other hand in comparison to the mini harvester performance with performance of Highlander thinning harvester (Kormanek and Kępa, 2016) the value is decisively lower because in this case the operational performance was as much as $18.74 \mathrm{~m}^{3} \cdot \mathrm{h}^{-1}$. The main reason for this difference is a much higher average volume of trees which were felled by Highlander which amounted to $1.017 \mathrm{~m}^{3}$. Another reason which may be taken into consideration also when comparing Fao Far mini harvester with Valmet harvester was much lower tree feed speed in the mini harvester head which affected bucking (fig. 2b) (both Valment as well as Highlander harvester during the research were equipped with heads with roll feed drive). Despite lower speed of feed, this type of a head is used in thinning because it has a quite simple structure, high reliability and low weight (Więsik, 2015). Additional reason behind the differences in the performance, which may be also taken into consideration in this case, was weak training and short experience of the mini harvester operator. Analysis of the performance within the operational time of shift of Fao Far mini harvester, which was 9.61 $\mathrm{m}^{3} \cdot \mathrm{h}^{-1}$, shows that it was decisively lower than the compared Valmet where it was 12.32 $\mathrm{m}^{3} \cdot \mathrm{h}^{-1}$, (Maksymiak and Grieger, 2008) or Highlander performance of which in the operational time of shift was $12.71 \mathrm{~m}^{3} \cdot \mathrm{h}^{-1}$ (Kormanek and Kępa, 2016). Also operational performance of the mini harvester was lower when compared to Ponsse Ergon machine (tree stand age 52 years) and achieved performance in the operational time of shift at the level of $11.25 \mathrm{~m}^{3} \cdot \mathrm{h}^{-1}$. By analysis of the obtained results one may state that performance of Fao Far 6840 mini harvester with Arbo $300 \mathrm{~S}$ head was in particular conditions lower than in comparison to machines of other makes. The basic reason for those differences is the average volume of trees in the felling site although the structure of the head is not without meaning (the applied feed system of the processed tree) or the operator's skills. Increase of the operational performance of Fao Far 6840 mini harvester may be achieved by extension of the working day of the shift. Taking into consideration high costs of machines one should aim at the most possible use during the day. According to Nurel (2008) based on the research, extension of the daily working time of the harvester from 8 to 12 hours results in shortening of the total time of performance of all tasks predicted for realization on a given area by $10 \%$ and as a result causes considerable reduction of unit costs of felling. On the other hand according to Szewczyk and Kulak (2015) extension of work by the use of the two-shift system and with the work by 250 working days causes reduction by half of the costs of felling which are incurred in case of one-shift work and 110 working days. Błuszkowska and Nurek (2016) also indicate the positive impact of a longer working day on the increase of operational performance of harvesters and thus the amount of harvested trees (better use of the machine) and reduction of the harvesting costs. Better training for the operator would also be crucial because in some instances it was poor (in particular in case of felling trees which was mentioned above). According to Brzózko and Dybcio (2007) the best skills, qualifications and poor experience of operators have a significant impact on the harvester's performance. 
Analysis of operation...

\section{Conclusions}

Based on the analysis of Fao Far 6840 mini harvester operation one may conclude that:

1. operational performance of the mini harvester operation cycle at the level of 12.14 $\left(\mathrm{m}^{3} \cdot \mathrm{h}^{-1}\right)$ as well as operational performance in the shift working time at the level of 9.61 $\left(\mathrm{m}^{3} \cdot \mathrm{h}^{-1}\right)$ was lower than in case of machines working in similar conditions,

2. lower machine performance was affected mainly by conditions of harvesting, low log volume (at the average $0.62 \mathrm{~m}^{3}$ ) and concentration of trees. The head structure (applied feed system), weak work organization (short time of a single 6 hour shift) and weak skills of the machine operator were additional factors that decreased the performance.

\section{Funding}

The study was financed from the subsidy of the Ministry of Science and Higher Education for statute activity.

\section{References}

BN-76/9195-01 Maszyny rolnicze. Podział czasu pracy. Symbole i określenia.

BN-77/9195-02 Maszyny rolnicze. Metody badań eksploatacyjnych.

Błuszkowska, U., Nurek, T. (2016). Wpływ czynników organizacyjnych na wydajność eksploatacyjną harwestera. Sylwan, 160 (6), 443-451.

Brzózko, J., Dybcio, M. (2007). Umiejętności, kwalifikacje i doświadczenie operatorów a wydajność pracy specjalistycznych maszyn leśnych. Technika Rolnicza Ogrodnicza Leśna, 3, 5-7.

Dvorak, J., Walczyk, J., Natov, P., Hośkova, D. (2015). Struktura czasu pracy harwesterów podczas pozyskania przygodnego. Sylwan, 159(4), 300-306.

Glazar, K., Maciejewska, H. (2008). Struktura czasu i wydajność pozyskiwania i zrywki drewna w drzewostanach sosnowych przy użyciu harwardera Buffalo dual. Inżynieria Rolnicza, 1(99), 111-118.

Inf. materials Fao Far - http://www.faofar.pl/.

Inf. materials of State Forests (2010). Technika Rolnicza Ogrodnicza i Leśna, 6, 4-7.

Jaszczak, R. \& Magnuski, K. (2010). Urządzanie lasu. Uniwersytet Przyrodniczy w Poznaniu. Poznań. 492.

Kormanek, M, Kępa, M. (2016). Analysis of performance of timber harvesting with the use of Highlander harvester. Agricultural Engineering, 20(3), 73-82.

Maksymiak, M., Grieger, A. (2008). Analiza wydajności pracy przy maszynowym pozyskaniu drewna na przykładzie harwestera Valmet 901.3 i forwardera Valmet 840.2. Inżynieria Rolnicza, 1(99), 273-281.

Mederski, P.S., Karaszewski, Z., Rosińska, M., Bembenek, M. (2016). Dynamika zmian liczby harwesterów w Polsce oraz czynniki determinujące ich występowanie. Sylwan. 160(10),795-804.

Moskalik, T. (2004). Model maszynowego pozyskania drewna w zrównoważonym leśnictwie polskim. Wydawnictwo SGGW Warszawa. 134. ISBN 83-7244-491-9 
Nurek, T. (2008). Analiza wpływu długości dnia roboczego na wyniki ekonomiczne pracy maszyn leśnych. Inżynieria Rolnicza, 1(99), 325-330.

Sadowski, J., Moskalik, T., Zastocki, D. (2014). Efektywność pozyskania drewna harwesterem PONSSE Ergo w wybranych drzewostanach. Studia i Materialy CEPL w Rogowie. 39/2B, 126-132.

Skarżyński, J., Brzózko, J. (2010). Harwestery do pozyskania drewna stosowane w polskich lasach cz. 1. Charakterystyka ogólna- nośniki. Technika Rolnicza Ogrodnicza i Leśna, $6,8-2$.

Sowa, J. M., Gielarowiec, K., Gaj-Gielarowiec, D. (2013). Charakterystyka i rozwój konstrukcji głowic harwesterowych do pozyskanie drewna. Prace Komisji Nauk Rolniczych i Komisji Nauk Leśnych, 105, 57-76.

Szewczyk, G., Kulak, D. (2013). Kosztochłonność pozyskania drewna harwesterem w drzewostanach przebudowanych z zastosowaniem cięć częściowych. Sylwan, 157(4), 243-252.

Więsik, J. 2015. Urządzenia techniczne w produkcji leśnej. Wydawnictwo SGGW. 591.

\title{
ANALIZA WYDAJNOŚCI PRACY W PROCESIE MASZYNOWEGO POZYSKANIU DREWNA MINI HARWESTEREM FAO FAR 6840
}

\begin{abstract}
Streszczenie $\mathrm{W}$ artykule przedstawiono analizę wydajności pracy mini harwestera Fao Far 6840, przy maszynowym pozyskiwaniu drewna. Analizę wykonano w oparciu o chronometraż dnia roboczego. Badania przeprowadzono na terenie Nadleśnictwa Lubliniec, Leśnictwo Bór na typie siedliskowym lasu bór mieszany świeży (BMśw), gdzie mini harwester pozyskiwał drewno sosnowe. Chronometraż wykonano w oparciu o rejestrację czasu eksploatacji harwestera przy pomocy kamery wideo i stopera oraz pomiarów pozyskanego sortymentu. Na podstawie uzyskanych wyników stwierdzono niskie wartości wydajności w eksploatacyjnym czasie zmiany $9,61 \mathrm{~m}^{3} \cdot \mathrm{h}^{-1}$, oraz wydajności efektywnej $12,14 \mathrm{~m}^{3} \cdot \mathrm{h}^{-1}$. Na niską wydajność maszyny wpłynęły przede wszystkim warunki pozyskania, niska miąższość (średnio 0,62 $\mathrm{m}^{3}$ ) i zagęszczenie drzew. Dodatkowymi czynnikami obniżającymi wydajność była konstrukcja głowicy (zastosowany system posuwu) słaba organizacja pracy (krótki czas trwania pojedynczej 6 godzinnej zmiany) oraz słabe umiejętności operatora maszyny.
\end{abstract}

Słowa kluczowe: harwester, pozyskiwanie drewna, wydajność harwestera 